RESEARCH ARTICLE

\title{
Understanding the Circulation of Songs of Resistance via Social Media in Manipur, India
}

Priti Laishram

Department of Sociology, Delhi School of Economics, University of Delhi, Delhi ، India

\begin{abstract}
Songs of resistance have been used widely to address the plight of people. They have served as a medium through which people could talk about oppression and injustice. They depict the reality and lived experiences of people. In addition, they reflect on the socio-political situation while, at the same time, questioning the state atrocities and also addressing the conflict between state and non-state actors, namely the armed underground organisation, the civil society organisations. This paper attempts to understand the circulation of songs of resistance in Manipur, India. As the use of cassette has stopped and selling CDs became financially non-viable for independent artists, social media has become one of the major channels to reach the audience. The artists who sing songs of resistance do not perform in street protests, and their songs are even not used in street protests. Concerts, crowd-funded events, and social media, then, have become a major means through which the songs are circulated. The current study discusses the role of social media in facilitating the circulation of these songs. The paper also addresses the issue of access and the role of fan pages in this process.
\end{abstract}

Keywords: resistance, songs, social media, circulation, concerts

\section{Introduction}

This paper attempts to understand the circulation of songs of resistance in Manipur, India. Concerts and crowd-funded events have always been a channel that plays a crucial part in the circulation of songs of resistance. As the use of cassette has stopped and also selling CDs became financially non-viable for independent artists, social media has become one of the major channels to reach the audience. Attending concerts and crowd-funded events have been part of the cultural life for the Meiteis ${ }^{1}$ in Manipur. It takes place during festivals and for specific purposes and causes. Unlike the protest singers who participate and perform in organised protests, the artists who sing songs of resistance do not perform in street protests, and their songs are usually not used in protests. The concerts, crowd-funded events, and social media, then, have become a major means through which the songs are circulated.

The fieldwork was conducted in two phases, the initial fieldwork was done between March and May 2016, and the second (and the main) fieldwork was conducted from March 2017

\footnotetext{
${ }^{1}$ Meitei is the dominant community in Manipur
} 
to November 2018 in Manipur. The data is collected using qualitative methods. The research focussed on the Meitei community in the valley of Manipur. The research used ethnographic study, which included participant observation and in-depth interview of artists and listeners. During the two phases of fieldwork, I attended 13 events and interviewed artists and the audience. These events and programs decided my field site.

\section{Literature Review}

Social science scholarship has built a nuanced understanding of the concept of resistance with its engagement with various acts of resistance (Hollander \& Einwohner, 2004; Johansson \&Vinthagen, 2014; Lilja, Baaz, Schulz \& Vinthagen, 2017). Hollander and Einwohner (2004) tried to understand the vast literature on it to investigate two vital aspects, firstly, the issue of recognition of an act of resistance by others and, secondly, the issue of intention. They argued that there had been an increasing shift of attention from the study of social control and social structure to the social agency in the research on resistance. Scott's $(1985,1990)$ work on everyday forms of resistance has played an instrumental part in the field of resistance studies. James Scott, in his book Weapons of the Weak (1985), has focused on peasant societies. He undertook an ethnographic study in Sedaka, a region in Kedah, Malaysia, and noted that the most subordinated class did not have the "luxury of open, organised political activity" (Scott, 1985, p. $\mathrm{xv}$ ). The everyday act of resistance failed to come under larger studies on resistance, but the author tried to explore this area and show how these forms of resistance were equally important as the larger collective resistance. In his later work, Domination and the Arts of Resistance (1990) Scott has expanded his analysis of everyday resistance to different cultures and societies. He talked about infra-politics. He explained that he meant "a wide variety of low-profile forms of resistance that dare not speak in their own name" (Scott, 1990, p.19). These forms, like the ones discussed in the peasant society, are shielded and given anonymity to the perpetrators of the act. The most important critique of Scott's work has been his generalisation of peasant societies and post-modern societies (Courpasson \& Vallas, 2016). Nevertheless, his contributions have pushed the study of resistance forward to new terrains where individuals and groups use whatever is at their disposal to question the power that looms over them.

Certeau (1984) furthered this idea of everyday life in his seminal work The Practice of Everyday Life wherein he discussed the strategies employed by the structure of power and tactics used by the powerless to manoeuvre around. Ordinary people, through their everyday practices, can negotiate with the dominant structure. He saw every day as a space of resistance. He marked the everyday acts of 'making or doing' as 'tactics' employed by individuals to negotiate the 'strategies' of the overarching structure of power that looms on them. Tactics are tools that weak and subordinates use. Songs here become part of the tactics both artists and audience/listeners use to address their experiences of living in a conflict zone.

In the case of songs of resistance, concerts, which are one of the means of circulation, are imbued with ordinary everyday practices which can be easily sidelined if we are looking for grand acts of resistance like armed struggle or street protest. The act of coming to these spaces, where concerts happen, can be seen as an act of resistance as people are fully aware of the artists and their work. The act of gathering and discussing activities around these spaces can be seen as mundane at face value. However, the space, where it happens, is already shaped by the event that 
is to happen. This work shows the negotiation of everyday activities and cultural practices that exist along with the everyday act of resistance. Social media also become a space where ordinary individuals come and exchange information and discuss their experience. This space which is safe but not completely free from scrutiny, given the growing encroachment of the state into these spaces, is still utilised by ordinary individuals to assert their voices of dissent. When it comes to resistance by ordinary people who have no power to confront the dominant forces, the need to look at the means they use to resist becomes crucial in understanding resistance.

Duncombe (2002), while discussing cultural resistance, argues that as culture is usually something which is shared, it becomes crucial in the building a community. Here, he also mentions that among other things, cultural resistance also provides free space. This free space brings individuals together to build networks and community. It also serves as a space where new ideas and practices can be developed. He discussed "how culture conveys its politics" and added that "a message can travel via the content of the message" (Duncombe, 2002, p. 6). He explained this with an example of Sex Pistols' song 'Anarchy in the UK' and pointed out the resistance in their lyrics. Songs have been used widely to highlight the plight of people while serving as a medium through which people could talk about oppression and injustice. The songs bring people together because they reflect and address their shared life experiences. Courpasson and Vallas (2016) argued that "resistance requires the contexts, selfhood, friendships and kinship connections, possibilities of empowerment and relations to the world, as well as a sense of community through which people care more and think more about what they can do together to feel better or simply to survive" (2016, p. 13). Through these songs of resistance, people come together and share their concerns and get a means through which they can voice their dissent.

Neustadt (2004) talked about the new song movement called Nueva Cancion in Chile, which played an important political role before and during Salvador Allende's socialist Unidad popular government. But later it became a pan Latin American phenomenon which was "a call for social justice from the left" (Neustadt, 2004, p. 128). The songs not only focus on the present problem faced by people but also on the past by celebrating their indigenous history and invoking their origins, aiming to find their lost race. In Venezuela, a similar kind of use of music took place. Carruyo (2005) explained how Gaita, which is a regional form of Venezuelan popular music, was used by people to talk about their lived experiences and a tool for protest. Gaitas are songs that were improvised and created collectively in the state of Zulia. The author said Gaita is a "fusion of African, indigenous and Spanish instrumentation and rhythms" (Carruyo, 2005, p. 98). Gaitas has a wide range of themes including religion, community, history and political protest. The music draws on "historical memory, local lived experience and regional symbols to create a sense of community and collective opposition to perceived injustice" (Carruyo, 2005, p. 98). Songs have always played a crucial role in highlighting the lived experiences of the marginalised and addressing oppression and injustice. Martinez (1997), while talking about rap music as a form of resistance, said rap music is an oppositional culture which talks about life in the inner-city poverty, marginality and racial and institutional discrimination faced by nonEuropean groups such as African Americans, American Indians and Mexican Americans. This oppositional culture helped the marginalised to address various issues that concern them and also to question the oppression they face. 


\section{Discussion}

Manipur is located in the north-eastern part of India. Till 1947, it was under British Paramountcy as an independent kingdom (Naorem, 1988; Arambam, 2018). After the British left in 1947, it established a democratically elected government through an adult franchise in 1948 with a constitution of its own. But, Manipur was merged with the Indian Union in 1949 (Kamei, 2016). Parratt and Parratt (2015) discussed the non-recognition of a democratically elected government by Independent India. They opined that independent India "which proclaimed its dedication to democracy wilfully refused to recognise the democratically elected government of its tiny neighbour, and instead persisted in dealing with the former feudal ruler, who himself repeatedly protested that he had surrendered his power to the elected assembly" (Parratt \& Parratt, 2015, p. 56).

After Manipur's merger with the Indian Union, Manipur was given Part C status which brought about a direct rule of the Indian state. Lokendro Arambam (2015) explained that Part C "erased the 'efforts of self-governance and people's democracy by Indigenous communities" (2015, p. 105). Many organisations came with an organised armed struggle to fight the Indian state, questioning its legitimacy and arguing that the Indian state has annexed Manipur to the Indian Union. The Indian state retaliated with 'the Armed Forces (Special Powers) Act, 1958' (AFSPA) and heavy militarisation in the Manipur. The presence of the armed insurgents still constitutes an important aspect of life in Manipur. Manipur has seen organised resistance in the form of the armed struggle waged by underground organisations and people's protest on the street organised by civil society organisations against the state violence. Under the leadership of Hijam Irabot, communists in the valley of Manipur organised the first armed struggle in 1948 against the monarch and the elected government according to the Manipur State Constitution 1947. The Indian state managed to suppress the movement by 1951 .

Hijam Irabot was an important political figure in Manipur. He was considered to be the one who started the communist movement in Manipur in the second half of the 1940s. Irabot's songs focused on the need for peasant resurrections, freedom movement against the British, women's contribution and need for unity among hills and the valley of Manipur and also between pangals (also known as Manipuri Muslims) and Hindus. He also helped establish the Indian People Theatre Association (I.P.T.A) ${ }^{2}$ movement in Barak Valley in Assam ${ }^{3}$. In 1964, Nongmaithem Pahari, who later became a renowned singer, became the founding member of United National Liberation Front (UNLF). UNLF demanded the right for the self-determination of Manipur, alleging that Manipur has been annexed to the India Union. Pahari, in his book 'Eigi Diary dagi' (From my diary), written in 2008 talks about the ban of his songs when he was arrested in 1969. When statehood was granted to Manipur in 1972, Pahari was given amnesty and he was released from prison. More groups were formed and the armed insurgency continued. Hijam Irabot and Pahari belonged to organisations which were engaged in resisting the state. Artists in Manipur today are part of the organisation called Apunba Manipur Matam Ishei

\footnotetext{
${ }^{2}$ IPTA is a theatre collective that was formed in 1940s pre-independent India which used street plays, songs, theatre to address socio political issues.

${ }^{3}$ Assam is another state in the northeast region of India
} 
Kanglup (AMMIK). Earlier, local TV channels did not televise any music videos produced by the artists who were not enrolled in the organisation, and without AMMIK's permission, nonmembers could not sing in Manipuri films. In May $1^{\text {st }}, 2018$, the organisation changed its rules to allow non-members to circulate their music via local TV channels, but their songs would still go through screening. AMMIK held access to Manipur Film Industry for the artists. A certain amount of money was also paid to AMMIK every time a member of AMMIK performed in a concert. It also screened the music before its release.

In the 1990s, two important bands, Eastern Dark and Tapta, were established. They sang about political and social issues. In 2009, another independent band called 'Imphal Talkies and the Howlers' (popularly known as Imphal Talkies) was established.

Eastern Dark was established by Heisnam Lokeshwar. During an interview, he told me he is questioning the section of people who are regarded as educated. He added that they can be politicians, professors, students, and activists etc. His songs talk about corruption, the hypocrisy of politicians, intellectuals, and various organisations.

Jayanta Loukrakpam, popularly known as Tapta (which is also the name of his band), established another band. His songs cover a wide range of themes. The songs talk about the life under AFSPA, the ethnic conflicts, corruption, and various social issues like the effect of mobile phone, the need for education, restaurant drive and so on.

In 2009, Ronid Chingangbam (popularly known as Akhu), the singer and songwriter of the band Imphal Talkies and the Howlers, came out with its first album Tiddim Road. Akhu's solo project, "A Native Tongue Called Peace" brings out songs with the children's care home called Carmel Jyoti in Imphal ${ }^{4}$. The songs that Akhu sings with the children address the conditions of children living in a conflict zone. Every year, Akhu and his team organise a festival called "Where have all the flowers gone?" In 2017 and 2018, the festival was held in Khurkhul, a village in Imphal west district. He said the purpose of this is to bridge the rural-urban gap about the environment and to promote local independent music and artists. Akhu's songs are political and he does not shy away from criticising both the State and non-state actors. His songs focus on life in a conflict zone. His songs bring out the day to day life of living under violence and talk about the need for peace. They also address the long-term effect of violence on people and especially children.

The songs from the artists mentioned above are what I refer to as songs of resistance. I refer to them as songs of resistance because these songs depict the reality and lived experiences of people. They reflect on the socio-political situation while, at the same time, questioning the state atrocities and addressing the conflict between state and non-state actors, namely the armed underground organisation, the civil society organisations.

As mentioned before, the artists do not perform in street protests and their songs are not used in organised acts of resistance. In Manipur, artists have used the space of concerts, crowdfunded events and social media to circulate their music. Social media becomes an effective channel through which songs of resistance are disseminated. The most important aspect of this

${ }^{4}$ Imphal is the capital of Manipur 
channel is how it could help the audience/listener connect to a place they have left or are away from. It helps people connect not only with the huge number of people who migrated to other parts of India for education and work, but also with the larger audience who are not from Manipur.

\subsection{Social Media}

Social media serves as a channel that forms an imagined community. Anderson (1983), while problematizing the widely used concept of Nationalism, proposed that the definition of nation is "an imagined political community - as imagined as both inherently limited and sovereign" (1983, p. 6). He argues that this nation is imagined because "the members of even the smallest nation will never know most of their fellow members, meet them, or even hear of them, yet in the minds of each lives the image of their communion" (Anderson, 1983, p. 6). As social media helps transcend borders, the fan pages and band's official pages become a space for people to access the latest music from the band and it also serves as a platform for discussions and debates. This space also becomes a medium through which information about upcoming concerts/events are posted. The music helps create a community where the place (homeland) takes importance. The members relate to the music because of the connection it creates between them and their home.

Taking Habermas' work on the public sphere, Kruse et al. (2017) discussed its relevance to examine if spaces like social media could be seen as constituting a public sphere. While doing so, they focused on the role of communicative action in bringing people to dialogue regarding various issues that concern them to facilitate a form of participatory democracy. They concluded that social media could not serve as a viable public sphere in spite of having its positives. They were concerned with surveillance and online abuse. However, it's important to point out that where there are no other means of circulation and when life offline is more under surveillance and movements are curtailed, social media serves as the best choice to the artists. In her paper 'Feminism and Social Media Sphere,' Kasana (2014) pointed out that Muslim women and other minorities have taken social media as a means to question beauty standards of the west, racism, xenophobia and also the saviour complex of the privileged. The question of access is a crucial one. The debate on who has access and who is excluded drew wide attention to the growing economic disparity and the political, social and cultural aspects of a society where women and minorities have no access or comparatively less access to social media. This does not negate the growing importance of the use of social media to redefine politics in the present time.

Social Media has largely helped in de-territorialization of resistance. Songs are widely circulated through social media, opening up the access to many groups, especially to women whose access to the physical spaces is curtailed. Social media also provides a platform through which information is circulated, solidarity is sought, and connections are made. Marche (2012), while talking about graffiti, pointed out that the act of resistance should engage with people's hearts and minds. It can be said that the long existence of songs as a form of resistance has more to do with how music engages with people's emotions. This interpersonal relationship and attachment are crucial in understanding the spread of music and attending concert/crowd funded events. Apart from the shared reality and experience of individuals or groups that are narrated in the songs, the songs are made and spread because of friendship and commitment. Online 
communities, like the social media pages of the band or its fans, provide a platform where individuals and groups with shared interest come together and discuss the songs, the artists and also about events. Consequently, this forms solidarity and what Anderson (1983) calls imagined community.

Bennett (2015) explained how the Internet helps to form new ways of understanding the relationship between music, self and community. In his work on the Canterbury sound, Bennett (2004) talked about how there is a connection between the Canterbury sound and the city of Canterbury through the various websites, discussions and debates which go beyond a particular location. This is true about songs of resistance and the fan pages of the artists/bands associated with this form of music. Here, unlike the intentional creation of a link between the music and location, the music itself speaks of the place and people and their experiences of living in a conflict zone. Individuals use social media to voice their opinions and narrate their experiences. Social media provides a sense of anonymity which acts as an advantage in a place where dissent is suppressed and citizens are stripped off their rights. In the context of Manipur, this platform has become a viable option for musicians to circulate their works. As mentioned before, as the use of cassettes has ceased and the use of CDs has declined, social media has become an appropriate means with low cost and, at the same time, with a capacity for wider dissemination.

With the spread of social media, the circulation has become easier and different. Tapta ${ }^{5}$ said, "When I compose a new song, and after recording the song, I tell my son and other associates to circulate it through social media like Facebook or Whatsapp." Akhu "said, "Nobody buys CD here, you might want to buy it because of your research, but nobody buys." When asked about the way he releases his music, he added, "we always release it online, but we did not release Tiddim Road online." It can be mentioned here that Tapta has a fan page on Facebook. Imphal Talkies has their band pages on both Facebook and Instagram where they update people about their upcoming events. The pages have become a space for the artist to connect with the audience. Akhu mentioned how recording and circulating through CDs is not feasible, and it is economically not a viable option for him as nowadays nobody buys CDs and people only listen to it online. All their songs are made available online on platforms such as iTunes, Reverb Nation, Sound Cloud, Spotify and YouTube. Compared to mainstream artists, their shows are also less. Due to a financial reason, even though independent artists are paid less, they are compelled to perform. Tapta, in this case, is an exception. He has been in the music scene since the 1990s. Due to his immense popularity, he has come to a stage where he can fix an amount and only perform if paid. Tapta explained that he is an artist and an activist, but also he has a family to look after. On the other hand, Akhu said that economic pressure makes them perform even if they are paid less. He said that sometimes if some band members need money, they decide to perform even if they are paid lesser than they expected. He added that most of the time they are not paid at all. In addition, they do not take money for performing in colleges. With the coming of the Internet and social media, the circulation has become easier and different. All respondents said that they first hear the song and come to know of the new songs through social media or through friends or family. A respondent $\mathrm{Naobi}^{7}$ said, "I never go to concerts, I only know of the songs

\footnotetext{
${ }^{5}$ Interview conducted on July 15, 2017

${ }^{6}$ Interview conducted on July 8, 2017

${ }^{7}$ Interview conducted on October 31, 2018
} 
when people forward it on Whatsapp or share it on Facebook." When I asked why she does not go to these concerts, she said, "I want to go sometimes but to ask for permission becomes an issue, I would rather sit at home than fight for permission at home." Social media has become a means through which the songs are accessed when going to concerts became infeasible. During an interview conducted with a respondent, I asked how she accesses the songs. Bony Nahakpam ${ }^{8}$ explained, "It is almost impossible for me and my sisters to get permission to go out. Men always have greater freedom when it comes to going out at night." She further said that she always knew about Tapta but "really started listening to him when a friend sent me a song on Whatsapp." Women do not have access to these spaces, but they have listened to the artist online and know about their work. Apart from the people in Manipur, the large number of individuals who migrate to other parts of India and abroad for education and jobs constitutes the members/followers of the fan pages or the band pages. Another interviewed respondent ${ }^{9}$ who studied in Russia said, "When I was in Russia, I used to miss home a lot. During that time, I used to listen to a lot of Manipuri songs. That's how I started listening to Akhu's. I could connect with his songs." Individuals access the songs through the updates on YouTube channels of the bands, Facebook fan pages, and official band pages.

\subsection{Facebook Fan Page}

Social media gave space for audience/listeners to connect beyond a specific geographical space. Fan pages in Facebook have not only created a space where people can access information about the artist's work but also have provided a space for interaction among followers and fans of an artist. Here, I would like to discuss one of the fan pages called "Tapta Songs \& Lyrics" which is run by a fan club with the same name. I met some of the members of the fan club in an event. The event was to celebrate the coming of a new year. It was $31^{\text {st }}$ December 2017, and the temperature in Imphal had dropped significantly. Tapta was requested to perform late and sing throughout the night as a way of welcoming the New Year. In this particular event, I met members of the fan club. Two of them (both men in their mid-20s) sat on the chairs which the organiser provided. The three of us formed a circle. I started explaining to them about my work and asked how the fan page works. Later another man entered and sat there. One of the men said he was the secretary of the fan club. He explained to me how they made certain rules in the club. He explained that they have a Whatsapp group which functions with a set of written rules. He looked for his phone and showed me the written rules. The rules specifically address the purpose of having a Whatsapp group and what is to be discussed. It clarifies how the group has to discuss issues related to Tapta only. He said that the group has a lot of female members and, therefore, males are not allowed to misuse the phone numbers of those females in the group. He added, if things like that happen, then the person will be removed from the group and the club. I asked more about their Facebook page. Sumanta ${ }^{10}$ (a member of the group) then responded that the page has many followers. He explained "there are many people involved in the functioning of the page. We constantly get messages from people asking about Tapta's song lyrics and about upcoming events." Loyumba ${ }^{11}$ (another member) added, "There are so many messages on the

\footnotetext{
${ }^{8}$ Interview taken on October 31, 2018

${ }^{9}$ Interview taken on July 12, 2018

${ }^{10}$ Interview taken on December 31, 2017

${ }^{11}$ Interview taken on December 31, 2017
} 
daily basis that we have now stopped replying to most of it" and further elaborated on how they have now made a blog for the lyrics. As for the events, they update it regularly. It can be mentioned that their page is very active. They constantly update their followers about any new song or any event where Tapta is going to perform. The fan club also runs a blog. The blog has posted lyrics of most of Tapta's songs. Loyumba said,

We all have contributed to it, and we still have to upload many. A fire broke out many years ago in the studio where Tapta used to keep all the cassettes. Due to the fire, a major portion of his work was lost. At that time, there was no internet, technology was very limited, and there was no way the materials could be preserved.

Sumanta added "there are more than 1000 songs that Tapta has done till now. But what people know now, and listen to forms only 500." Sumanta explained to me that the club usually celebrates the foundation day of the fan club. Speaking about the foundation day celebration of 2017, he said "there is a huge reason why we had to organise it in a grand manner. You must be familiar with the new movie Keishal." Keishal is a movie whose making Tapta was part of. As Tapta was not part of AMMIK, it was banned for some years. The ban lifted in December 2017. He said, Tapta fan club played a major role in the release of the movie. He said, "We can say we lobbied a lot." He then explained that the foundation day is mostly organised to show some people how Tapta also has supporters and to send a strong message to people who are against Tapta. He said AMMIK is a large and powerful body that supports Tapta. As mentioned above, Tapta is not part of the AMMIK and is an independent artist which means he is not allowed to sing in any Manipuri Film. Unlike Tapta, Imphal Talkies have their own Facebook and Instagram pages which the band manages. They update their followers about their new songs and share the details of their upcoming events as well. Imphal Talkies and Tapta have their YouTube channels where they upload their music.

\section{Conclusion}

The songs of resistance reflect the reality and experiences of the people living in a conflict zone. The means of circulation of these songs becomes an important part in understanding resistance. Social media helped artists circulate the songs and enabled audiences/listeners to access the songs conveniently. In the interviews, artists said that Manipur has no market for independent music. Social media has helped artists to disseminate their music without having to worry about the financial costs. It also helped the audience/listeners to come in contact with each other and also enabled artists to move beyond the geographical barriers. It helped create a community of individuals who do not meet and do not know each other but, at the same time, share similar interest in music. Through social media platforms, the songs bring individuals and groups together. In addition, people take part in the political dialogue through social media platforms. Social Media became crucial not only as a medium to connect with a large number of the youth who left the state for various reasons, but also it helped to reach out to the world. It also became a space to bring about a shared and collective identity that fosters a sense of solidarity.

\section{References}

[1] Anderson, B. (1983). Imagined communities. Verso. 
[2] Arambam. L. (2015). Narratives of self-determination struggles in Manipur. In Hanjabam. S. S, Hanjabam. H. \& A. K. Singh (Eds.), Self determination movement in Manipur (pp. 83125). Concept Publishing Company.

[3] Arambam. N. (2018). 1949 The Story of India's Takeover of Manipur. Manipur.

[4] Bennett, A. (2004). New tales from Canterbury: The making of a virtual scene. In A. Bennett \& R. A. Peterson (Eds.), Music scenes local, translocal and virtual (pp. 205-220). Vanderbilt University Press.

[5] Bennett, A. (2015). Identity: Music, community, and self. In J. Shepherd \& K. Devine (Eds.), The Routledge reader on the sociology of music (pp. 143-151). Routledge.

[6] Carruyo, L. (2005). La Gaita Zuliana: Music and the politics of protest in Venezuela. Latin American Perspectives, 32(3), 98-111.

[7] De Certeau, M. (1984). The Practice of everyday life (S. Rendall, Trans.). University of California Press. (Original work published 1980)

[8] Duncombe, S. (2002). Introduction. In S. Duncombe (Ed.), Cultural resistance reader (pp. 126). Verso.

[9] Hollander, J and Einwohner, R. (2004). Conceptualizing resistance. Sociological Forum,19(4), 533-554.

[10] Johansson, A and Vinthagen, S. (2014). Dimensions of everyday resistance: An analytical Framework. Critical Sociology, 42(3), 417-435.

[11] Kamei, G. (2016). A History of Modern Manipur 1826-2000 (A study of Feudalism, Colonialism and Democracy). Akansha Publishing House.

[12] Kasana, M. (2014). Feminisms and the social media sphere. Women's Studies Quarterly, 42(3-4), 236-249.

[13] Kruse, L. M., Norris, D. R and Flinchum, J.R. (2017). Social media as a public sphere? Politics on social media. The Sociological Quarterly, 59(1), 1-23.

[14] Lilja M, Baaz M, Schulz M and Vinthagen S. (2017). How resistance encourages resistance: Theorizing the nexus between power, 'organised resistance' and 'everyday resistance'. Journal of Political Power, 10(1), 40-54.

[15] Marche, G. (2016). Graffiti as infrapolitics: A study of visual interventions of resistance. In S. Francisco (Eds.), The SAGE handbook of resistance. (pp. 336-350) SAGE Publications Ltd.

[16] Martinez, T. (1997). Popular culture as oppositional culture: Rap as resistance. Sociological Perspectives, 40(2), 265-286.

[17] Naorem, S. (1988). The genesis of insurgency. In N. Sanajaoba (Ed.), Manipur past and present: The heritage and ordeals of a civilization (pp. 245-290). Mittal Publications. 
[18] Neustadt, R. (2004). Music as memory and torture: Sounds of repression and protest in Chile and Argentina. Chasqui, 33(1), 128-137.

[19] Pahari, N. (2008). Eigi Diary Dagi [From My Diary]. Panthung Computerised Printer.

[20] Parratt, J. \& Parratt, A.S.N. (2015). Integration or annexation? Manipur's relation with India 1947-1949. In S. S. Hanjabam, H. Thangjam \& A. K. Singh (Eds.), Self determination movement in Manipur (pp.44-62). Concept Publishing Company Pvt. Ltd.

[21] Scott, J. C. (1985). Weapons of the weak: Everyday forms of peasant resistance. Yale University.

[22] Scott, J. C. (1990). Domination and the arts of resistance: Hidden transcripts. Yale University.

[23] Vallas, S., \& Courpasson, D. (2016). Critical introduction. In S. Vallas, \& D. Courpasson, (Eds.), The Sage handbook of resistance (pp. 1-29). SAGE Publications Ltd. 